\title{
Mechanisms in the Formulation of the Management Policy in the Informal Sector in Makassar
}

Rahman Bebasa

Chalid Imran Musa

Rifdan

Thahir

\section{Gufran D. Dirawan}

Universitas Negeri Makassar, South Sulawesi, Indonesia, Jln. Bonto Langkasa Kampus Gunung Sari Baru Postal Code 90222, (Study of Street Vendor); bebasarahman@gmail.com, imranmusa19@yahoo.com rifdan@unm.ac.id, gufrandarma@yahoo.com

Doi:10.5901/mjss.2016.v7n3s1p367

\section{Abstract}

This study aimed to analyze the mechanisms of policy formulation and management of the informal sector (street vendors) in Makassar. The location of research at the Office of Trade and Small and Medium Enterprises of Makassar and Office of CivilService Police Unit of Makassar. The type of research was a case study with a qualitative description. The analysis model was designed such that research can reveal important issue related to the focus of the research problem. The informant is composed of the Regional Secretary of Makassar, head of the Department of Trade and Cooperatives as Key informants, while the Civil-Service Police Unit, small and medium entrepreneurs as informants. Data handles by observation, interview and documentation. Data analysis technique was used starting with data collection, condensation, data presentation and conclusion. The results showed that (1) The existence of street vendors as part of the entrepreneur with low-economic is one of the potential socio-economic in Makassar that supports regional development. (2) The activity of street vendors in the city of Makassar is not running well rise to urban problems like the aesthetic, traffic, disruptive pedestrian and environmental hygiene. (3) Local Government of Makassar has conducted coaching, guiding and counseling for street vendors and (4) Policies Government of Makassar asked all vendors, they must be registered and licensed by Makassar Government.

Keywords: Policy, Informal Sector, and Street Vendor

\section{Introduction}

Policy mechanism begins by identifying policy issues, Dye (2013). To identified the problem, the next step is the formulation of a policy to use cycle perspective with emphasis on feedback, Jan and Wegrich (2007). In the end, the policy continues to be assessed, controlled, modified and sometimes middle of the road when it is not fit it can be done cessation.

Similarly, the policy of urbanization, the city planning and informal sectors, namely street vendors. It continued assessment along with the development of urbanization itself. The process of urbanization, in general, can be due to two factors: push and pull factors (Koncoro, 2003). With these factors, the developments of street vendors are made an effort, kinship, low in formal education, low-scale activity, easy to encompass all walks of life; capricious, unstable and lowincome level, Manning (1996).

The weakening of the Indonesian economy, including Makassar, make the existence of street vendors be selected as the backbone of the economy in addressing the high unemployment rate. The weak economic situation, as security vendors to accommodate the number of people entering the world of work, while waiting for the economy to improve, Simanjuntak (2005).

Street vendors or PKL (Pedagang Kaki Lima), is a community that mostly sells by utilizing the area along the main road to seek sustenance to trade their wares or cart-lane highway roadside. With the land that allows traders to trade while waiting for buyers.

Over time, Many Street vendors that use the site as a place to sell, so invite pedestrians passing by to buy food, 
drinks while resting. Therefore, the Dutch government was called the pedestrians originator of merchants who sell in the area of pedestrians or sidewalks that have five feet wide, Gani (2014).

Today, there are no residential sidewalks with distance, so that the manufacture of the gardens on the side of the road seems improvised and unable to occur when rainwater infiltration. This error does not entirely lie in vendors as a nuisance of road users. In this case, the government should be quicker to take action and enforce regulations. Looking for jobs also supports the proliferation of vendors who are over the profession due to termination of employment and so forth.

The terms of street vendors long were known in Indonesia. The term has Thus, since 1811 to 1816 when Napoleon Bonaparte controls of the European continent and Dutch colonies in Asia were at the British administrative power. At that time, the Governor General in Indonesia was Sir Thomas Stanford Raffles instructed the traffic system on the left on the road. At the same time issued a regulation that at the edges of the road must be made sidewalks for pedestrians whose height is should be 31 centimeters, and the width is 150 centimeters or as five feet. Five feet from the words of the traders who conduct business on the sidewalk dubbed the pavement, Thoha (2009).

A policy analysis by Dunn (2000) is the activity of creating knowledge about policies and policy-making process In creating the knowledge of the policy-making process of analysis; policy analysis examines the causes, effects and performance of public policies and programs. The knowledge is incomplete if it is given to policymakers and the public to whom the obligation analysis served. Only if knowledge about the policies associated with knowledge in the policy process, members of the executive, legislative and judicial branches along with citizens who have a role in the decisions of the public, can use the results of the analysis of policies to improve the process of policy-making and performance. Because knowledge is available, communication and the use of policy analysis become important in the practice and theory of public policy making.

Solving the problem is a key element in policy analysis methodology. As important as it is, policy analysis is to formulate the problem as part of the search for solutions. By asking the right questions, the problem cannot be solved previously sometimes can be reformulated to find a solution that was not earlier detected. When that happens, the phrase no solution, no problem can be replaced with the phrase a problem well-defined is a problem half-solved.

Policy analysis methodology according to Beethem (1990) and Albrow (1996), states that the methodology of policy analysis was taken from combining elements from various disciplines, such as political science, sociology, psychology, economics, philosophy. Policy analysis is descriptive, which is derived from the traditional disciplines (political science, State science) to find out about the causes and effects of public policies. However, also prescriptive policy analysis, the goal is to create and perform a critique of knowledge claims about the value of the public policy for generations past, present and future. Alternatively, critique prescriptive aspect of the value of policy analysis is seen when we realize that knowledge relevant to policy includes an analysis of the dynamics between the dependent variable and independent variables that are fluctuating.

In Makassar, street vendors significantly with the increasing number of merchants who occupy section's highway, patio stores, public facilities land even sidewalks for business activities. Thus, street vendors disturb the activities of the community because it is not an area of street vendors.

Nevertheless, street vendors are the potential city of Makassar and Regional Government of Makassar needs to regulate and organize the street vendors to make policy regarding the formal sector in these case street vendors.

\section{Methodology}

The research was conducted in the city of Makassar. The research was used qualitative research with case study approach. The qualitative research was chosen to analyze in depth the phenomenon of the problems of street vendors in the city of Makassar. Qualitatively, the study could describe the real situation on the ground, as well as to describe, summarize a variety of conditions or phenomena associated with the reality of street vendors.

Sources of research data are street vendors as key informants. The number of street vendors of 10 people, group of street vendors of 11 people, and supervisor of groups of two people. Other informants namely Head of Department of Trade and Industry, Head of the Department of Cooperatives and Small and Medium Enterprises, the Head of CivilService Police Unit of three people, Head of District of four people, and headman of six people.

Sources of data in this study were primary data. Data obtained through in-depth interviews and structured, following through observation with direct interaction to get data from a street vendor.

Secondary data was data obtained indirectly through an intermediary medium (obtained and recorded by the other party). Generally in the form of evidence, records or historical reports that have been arranged in the archive (documentary data) published and unpublished. 
The focus of research is How Mechanism Informal Sector Management Policy (Street Vendor) in the city of Makassar. The description of the mechanism of policy management focus is the unofficial sector (street vendors) in Makassar. It is a policy of Local Government in managing the informal sector (street vendors) in the perspective of sustainable development in the city of Makassar.

Researchers as the main instrument were used the tools of data collection, interview, documents and observations. Examination of the validity of the data followed the criteria of Nasution (1992) and Moleong (1993), the degree of trust, data reduction, data presentation and verification, and conclusion.

\section{Research Result}

\subsection{Management Policy in Informal Sector (Street Vendors).}

Street vendors in the city of Makassar in carrying out trading activities have not been organized properly, causing disruption to traffic, the beauty and cleanliness of the environment. Therefore, necessary guidance by issuing the rule of law, namely the Regional Regulation No. 10 of 1990 on Building of street vendors. Coaching and counseling to street vendors in hopes of the informal sector are well ordered and can increase revenue (PAD/Pendapatan Asli Daerah).

Makassar City Government in implementing the guidance to provide guidance and to consult as well as organizing the efforts of vendors. Regional Regulation No. 10 of 1990 on Street Vendors mandated that all street vendors must be registered and received permission from the local government of Makassar. With registered vendors and obtain permission from the local government of Makassar, it is expected that more vendors feel the tranquility in the trade because it is not brushed again by the Civil-Service Police Unit.

To that end, needs to be maintained order regulated and supervised by the Civil-Service Police Unit officers, including the head of sub-district and head of the village. Thus, it is expected that each day increasingly better management of street vendors and give effect to the arrangement of the city, including traffic, the beauty and cleanliness of the environment.

Activity vendors are expected by the Makassar City Government to spearhead the economy and energy into crimes in urban land. Besides that, the activity of street vendors could support the economy in the face of the economic crisis at the moment.

\subsection{Local Government City of Makassar Targets in Structuring Street Vendors}

The rapid development of cities and the increasing urban population growth and the high number of job seekers, the informal sector is growing. Street vendors are absorbing the largest labor in Makassar and impact on city planning, traffic, beauty, and cleanliness.

Street vendors contribute significantly to local revenues of Makassar. Nearly 35 percent of the regional revenue of Makassar in this informal sector. Therefore, the provision empowers man against street vendors should continue towards the beautiful urban arrangement, jam-free and security.

Makassar City Government is obliged to organize the presence of street vendors and the resulting traffic jams, spoil the beauty and trash. Therefore, the Makassar City Government handles the existence of street vendors.

Local Government in fostering and counseling must be patient and continuously. Thus vendors become the frontline in the arrangement of Makassar.

Local Government through the Department of Cooperatives is responsible for fostering vendors through the provision of counseling about the beauty of the city, hygiene and traffic order. Department of Cooperative together with the Department of Trade is training on financial management and how to gain access to the bank. Also, it also conducted outreach on trade license and obligations of the vendors.

Department of Trade and Department of Cooperatives not only nurtures and educates but at the same time facilitates the street vendors to obtain funds from banks. Thus the awareness of vendors that Local Government Makassar notices them. Street vendors also help the Government realize that the city is clean, beautiful and comfortable as well as safe.

Thus, street vendors are expected to participate as well as keeping the arrangement of the city those are by selling at a place that has been provided to trade, maintaining the cleanliness, security and agitate the traffic order. 


\subsection{Mechanism of Street Vendors Management}

Street vendors are hawkers in the city of Makassar. It is one of the socio-economic potentials of the community who gave a significant role to the development of Makassar; the street vendors can provide some community needs at affordable prices.

As a supplier of goods to the lower classes, it means that vendors have implemented social economy. The supply of goods to the lower classes of society makes the amount of money circulating in the formal sector is promising and contributing in dealing with the economic crisis.

The presence of street vendors created new jobs that can absorb labor. Therefore, it can reduce the number of unemployed. Besides that, the street vendors to contribute in terms of PAD of Makassar, which is a fund for development of the city.

Formal sector labor absorption through street vendors, reducing the burden of Makassar City Government in handling labor continues to rise. The government should further improve its policy towards street vendors so that street vendors can quietly carry out their activities in the trade.

Street vendors need security in trade activities. Due to the security and comfort of the street vendors can do a lot more trading activity and the amount of money circulating in the community is increasing.

The position of Makassar City Government set up the mechanism is to determine/regulate a courtyard that can be used to trade with street vendors, groups, and individuals. The fact is the street vendors have not organized and directed.

\section{Discussion}

\subsection{Management Policy in Informal Sector (street vendors)}

Makassar City Government has issued Local Regulation Number 10 of 1990 on the Development of street vendors. It regulation is issued to street vendors to conduct its activities do not interfere the traffic, beauty and cleanliness of Makassar.

Regional Regulation Number 10 of 1990 on Building Street vendors in implementation are expected more support and synergy between the vendors with the Makassar City Government. Thus this synergy will give effect to the vendors to move without being threatened Civil-Service Police Unit and provide benefits to the Makassar City Government to help the sector of employment, people's economy running and structuring a beautiful city, clean, comfortable and safe.

In carrying out the development through guiding and counseling, have not been effective in managing the street vendors that still agitate traffic order, beauty, and cleanliness. Makassar city government must be firm in implementing the Regional Regulation No. 10 of 1990 on the Development of street vendors.

Street vendors that have followed the guidance, counseling and entrepreneurship training shall maintain order, beauty and cleanliness of Makassar. Makassar city government should be firm with vendors who violate these regulations.

Organizations such as the District, Village coupled with the Civil-Service Police Unit, in its region to act firmly against vendors who perform trading activities without regard to the traffic order, beauty and order. Street vendors must know their rights and obligations contained in the regulation.

\subsection{Target the Local Government of Makassar City in the arrangement of Street Vendors}

The increasing movement of people annually from rural to urban areas, it becomes a burden on the city government to address the urbanization. Limited employment opportunities in city areas, leading to metropolitan dwellers looking for an alternative business that is street vendor business.

A street vendor is an alternative business activity that creates employment and contributes to the development of the city. Also, street vendors contribute to PAD of Makassar. Therefore, vendors need an arrangement through coaching, counseling and training and thus vendors in conducting its activities while maintaining traffic order, beauty, and cleanliness.

Technically, coaching is done by the Department of Cooperatives and Department Trade to perform a variety of counseling provision of continuous and sustainable. Thus structuring the activities of street vendors can be realized and Local Government target of Makassar on fostering Street Vendor by Regulation no. 10 of 1990 can be realized, which Reforming Makassar orderly, beautiful and clean to the World City.

Also, street vendors as potential social economy needed to be better, to absorb more labor. Thus, the problem of the urban labor force is increasing every year can be resolved. 


\subsection{Management Mechanism of Street Vendors}

The need of metropolitan communities is increasing every year, so it is necessary to meet their needs with affordable goods through street vendors. Through street vendors, middle communities easily meet their needs.

Because of the low economic community needs are so great through street vendors. While the facilities provided for limited trade, the alternative where business activities are on the road or sidewalk or anywhere that the vendors can deal. Thus, vendors cause congestion, trash everywhere and disturbing beauty of the city.

Makassar city government do management mechanism of a street venor to define, organize a place to perform trading activities. Makassar city government must be firm with vendors who perform outside activities that have been determined by the Government of Makassar.

Through the coordination of the Mayor of Makassar to the head of sub-district, head of the village and the CivilService Police Unit, the activities of street vendors can be controlled and does not interfere with urban planning. Thus, the street vendors as socio-economic activities that are an alternative to absorb the city labor can be developed further so that the city remains orderly, beautiful, clean, and safe at Makassar of the World City.

\section{Conclusion}

It is necessary for street vendor arrangements whom socioeconomic absorbing labor through coaching, counseling, and training. Thus, street vendors do not cause interference traffic order, beauty and cleanliness of the city.

\section{Suggestion}

Following several recommendations for the government to address the issue of street vendors:

1. It is hoped that municipalities can act decisively in enforcing the application of PP 10, 1990 of street vendors.

2. The need for the municipality to organize street vendors by providing space for street vendors to trade in every districts.

3. The government is expected to provide the best service for both capital and facilities of street vendor space to trade.

\section{References}

Albrow, Martin. (1989). Bureaucracy. (Translated by A. Rusdi Karim and Totok Daryono). Jogjakarta: PT. Tiara Wacana.

Ali, Farid., \& Alam, A Syamsu. (2012). Study of Government Policy, Rapika Aditama.

Anonim. (n.d). History of Makassar City. Retrieved from: http://makassar-kota-metropolitan.blogspot.com/p/sejarah.html (Accessed on 13 December 2014).

Basrowi., \& Susilo, Suko. (2006). Democracy and Human Rights. Kediri: Jenggala Pustaka Utama.

Biro Hukum dan Hubungan Masyarakat Badan Pertanahan Nasional. (1994). Land Acquisition for Development for Public Interest and Related Regulations. Jakarta: Yayasan Bhumi Bhakti Adhiguna.

Bovaird, Tony., \& Loffler, Elke. (2003). Public Management and Governance. England: New Fetter Lane, London.

Bromley, R. (1979). Urban Informal Sector: Why Is It Worth Discussing? The Urban Informal Sector Critical Perspectives on Employment and Housing Policies. Oxford: Pergamon Press.

Budihardjo, Eko. (1997). Urban Land use Plan. Bandung: Alumni.

Campbell, Tom. (1981). Seven Theories of Human Society. Oxford University: Claredon Press.

Cullen B. Ronald., \& Cushman. P, Donald (2000). Transitions to Competitive Government, Speed, Consensus and Performance. Albany: State University of New York Press.

Daldjoeni N. (1992). Circumstances of Society. Bandung, Alumni.

Downs, Anthony. (1967). Inside Bureaucracy. Boston: Little Brown and Company.

Dunn, William N. (2000). Introduction to Public Policy Analysis. (2nd Ed). Yogyakarta: Gajah Mada University Press.

Dvorin, P. Eugene., \& Simmons. H, Robert. (2000). Dan Amoral until Humanism Bureaucracy. Jakarta: Prestasi Pustakaraya.

Dwiyanto, Agus. (2002). Reformation of Public Bureaucracy in Indonesia. Yogyakarta: Galang Printika.

Evans, B. Peter. (1985). Bringing the State Back In. Melbourne: Cambridge University Press.

Evers, Hans Dieter. (1995). Urban Sociology, Urbanization and Land Dispute in Indonesia and Malaysia. Jakarta: LP3ES.

Faisal, Sanapiah. (1990). Qualitative Research of Basics and Applications. Malang: Yayasan Asah Asah Asuh.

Fatchan, A.H. (2009). Qualitative Research Method. Kediri: Jenggala Pustaka Utama.

Farazmand, Ali. (2002). Administrative Reform in Developing Nations. USA: Greewood Publishing Group.

Fischer, Frank., \& Siriani, Carmen. (1984). Critical Studies in Organization and Bureaucracy. Philadelphia: Temple University Press.

Firdausy, C. M. (1995). Model and the Informal Sector Development Policy Street Vendors. Jakarta: Dewan Riset Nasional dan 
Bappenas Puslitbang Ekonomi dan Pembangunan LIPI Indonesia.

Frederickson, George H. (1980). New Public Administration. Alabama: The University Of Alabama Press.

Fredericksan, George H., \& B Smith, Kevin. (2002). The Public Administration Theory Primer. USA: Westview Press.

Fox J, Charles., \& Miller T, Huch. (1995). Postmodern Public Administration. London: SAGE Publications.

Giddens, Anthony. (1985). Modem capitalists and Social Theory, An Essay Analysis of Marx, Durkheim and Max Weber. Jakarta: Universitas Indonesia (Ul-Press).

Goodnow J. Frank. (1914). Politics and Administration a Study in Government. London: The Macmillan Company.

Hakim, Abdul. (2008). Social Dynamics of Rural Community Economic. Malang: Lembaga Penerbitan dan Dokumentasi FIA Unibraw.

Henry, Nicholas. (1995). State Administration and Public Issues. (Translated by Lusiana D. Lontoh). Jakarta: PT. Raja Grafindo Persada.

Haryono. (2004). Informal Sector Workers against Policy, Analysis on the Control of Street Vendors in Batam. Thesis UNSU. Retrieved from: http/www.Google.Com.//Depts/dh/resquide (accessed on 22 February 2008).

Miami. (2002). Urban Development Strategy in Indonesia. Surabaya: Usaha Nasional.

Imam, Subekti. (2005). Demolition of Street Vendors, Tourism and Income impacts Against Street Vendor. Yogyakarta: FE-UGM. Retrieved from: http//www.Google.Com.//Depts/dhl/resguide,PenertibanPKL.html (accessed on 22 February 2008).

Ihami. (1990). Urban Development Strategy in Indonesia. Surabaya: Usaha Nasional.

Irawati, Tekom. (2013). Geographic of Makassar. Retrieved from: http://2012-52-039.blogspot.com/2013/04/letak-geografismakassar.html (Accessed on 13 December 2014).

Islamy, M. Irfan. (1991). Principles of State Policy Formulation. Jakarta: Bina Aksara.

Kamala, Chandra., \& Isono, Sadoko. (1994). Dynamics of Informal Economy in Jakarta, Recycling Industry, Pedicab and Street Vendors. Jakarta: Universitas Indonesia.

Killian, Jerri., \& Eklund, Niklas. (2008). Handbook of Administrative Reform an International Perspectives. USA: CRC Press.

Kooiman, Jan. (1993). Modern Governance, New Government-Society Interactions. London: SAGE Publications.

Manning C., \& Tadjudinm, Noer. (2001). Urbanization, Unemployment and the Informal Sector in the City. Jakarta: Yayasan Obor Indonesia.

Manning, Chris., \& Effendi, Noer Tadjudin. (1985). Urbanization, Unemployment and the Informal Sector in the City. Jakarta: Gramedia.

Makmur. (2007). Pathology and Treatment in Administration and Organization. Bandung: PT. Refika Aditama.

Marbun., \& Aji S.A. (2004). Control of City Planning. Jakarta: Erlangga.

McCarthy, Thomas. (1982). the Critical Theory of Jurgens Habermas. Massachusett: MT Press.

Moleong, J. Lexy. (2000). Qualitative Research Method. Bandung: PT. Remaja Rosdakarya.

Muluk, Khairul. (2002). Maps Concept and Local Government Decentralization. Malang: Lembaga Penerbitan dan Dokumentasi FIA Unibraw.

Mulyana, Deddy. (2002). Qualitative Research Methodology, New Paradigm Science of Communication and Social Studies. Bandung: PT. Remaja Rosdakarya.

Mustofa. (2008). Law of Urban Planning and Land Use in Juridical Technical Perspective. Jakarta: Yayasan Karya Dharma.

Norton, Alan. (1994). International Handbook of Local and Regional Government, A Comparative Analysis of Advanced Democracies. Aldershot: Edward Elgar Publishing Limited.

Pamudji, S. (2005). Urban Coaching In Indonesia, Overview and Aspects of Public Administration. Jakarta: Yayasan Karya Dharma.

Pierre, Jon. (1999). Debating Governance. New York: Oxford University Press.

Peters, Guy B. (2001). The Future of Governing. USA: University Press of Cansas.

Prijono, Tjiptoherijanto. (2001). Urban Informal Sector and Employment Issues, Jakarta: Majalah Prima 5.

Purwanto, Agus Erwan., \& Kumorotomo, Wahyudi. (2005). Public bureaucracy in Political System Semi-Parliament. Yogyakarta: Gava Media.

Ramli, Rusli. (1992). Informal Sector Urban Street Vendors. Jakarta: Ind-Hill-Co.

Rawls, John. (1971). A Theory of Justice. Massachusetts: The Belknap Press of Harvard University Press, USA.

Ronald. (1975). Public Administration. New York: The Ronald Press Company.

Rukmana D.W. (1993). Management of Urban Infrastructure Development. Jakarta: LP3ES.

Sanderson, K. Stephen. (1993). Macro Sociology, an Approach to the Social Reality. Jakarta: Rajawali Press.

Santoso, Panji. (2009). Theory and Application of Good Governance. Bandung: Rapika Aditama.

Sethuraman, S. V. (1991). Informal Sector in Developing Countries. Urbanization, unemployment, and the Informal Sector in the City. Jakarta: Yayasan Obor Indonesia.

Shafritz, M. Jay., \& Hyde C. Albert. (1978). Classics Public Administration. California: Brooks/Cole Publishing Company Pacific Grove.

Srnambela, Poltak Lijan. (2008). Public Service Reform, Theory, Policy and Implementation. Jakarta: Bumi Aksara.

Soeprapto, Riyadi. (2003). Bureaucratic Ethics Public Sector Governance and Accountability. Malang: Riyadi Press.

Soto, De Hernando. (1991). There is no Other Way, Hidden Revolution in the Third World. Jakarta: Yayasan Obor Indonesia.

Sugiono, Muhadi. (2006). Antonio Gramsci criticism against Third World Development. Yogyakarta: Pustaka Pelajar.

Surbakti, Ramlan. (1994). Urban Planning and Urban Infrastructure Development in Surabaya. Surabaya: FE-UNAIR.

Susilo, Suko. (2009). Understanding Ethics Bureaucracy. Kediri: Jenggala Pustaka Utama.

Straus, Anselm., \& Corbin, Juliet. (2003). Basics of Qualitative Research, restructuring measures and techniques Theoretical Data. (Translated by Muhammad Shodiq dan Imam Muttaqin). Yogyakarta: Pustaka Pelajar.

Stroink, MAT. (2006). Understanding of Deconcentrated. Bandung: PT. Refoka Aditama. 
Tjandra, Riawan., Kurniawan, Agung., Estiningsih, Muji., \& Hilal, Eko. (2005). Increasing Capacity of Local Government in the Public Service. Yogyakarta: Pembaharuan.

Thoha, Miftah. (2008). the Indonesian Government Bureaucracy in the Reform Period. Jakarta: Kencana Prenada Media Group. Wicaksono, Widya Kristian. (2006). Administration and Government Bureaucracy. Yogyakarta: Graha IImu.

Wikipedia (2015). City of Makassar. Retrieved from: http://id.wikipedia.org/wiki/Kota_Makassar (Accessed on 13 December 2014). Yustika., \& Ahmad, Erani. (2003). State VS Poor People, Culture and Problems of Industrialization. Bandung: Pustaka Pelajar. Zauhar, Soesilo. (1996). Administrative Reform, Concept, Dimensions and Strategies. Jakarta: Bumi Aksara.

Zhijian, Zhang., \& Guzman De P, Raul. (1992). Administrative Reform Towards Promoting Productivity in Bureaucratic Performance. Manila: Europe Secretariat General. 